\title{
DESIGNING A LESSON PLAN FOR INDONESIAN ADULT STUDENTS BY USING TBLT (TASK BASED LANGUAGE TEACHING)
}

\author{
Muhammad Ahkam Arifin \\ ahkam.arifin@gmail.com \\ Institut Parahikma Indonesia
}

\begin{abstract}
This paper starts with the introduction concerning the development of the pedagogical implementation of second language acquisition (SLA) from communicative language teaching (CLT) to task based language teaching (TBLT). Within the same section, the definition of a task is also provided. It then continues to the design of the lesson plan by implementing the six-step model for TBLT as suggested by Nunan (24); the rationale for each of the step is presented. Lastly, it culminates with the evaluation over the principles applied in the design of the lesson plan.
\end{abstract}

Keywords: task based language teaching (TBLT), TESOL methodology, communicative language teaching (CLT)

\section{A. INTRODUCTION}

I

$\mathrm{n}$ the past twenty five years as a result of finding an alternative way of teaching effective strategies due to the constraints of the concept of method (Kumaravadivelu, 2001), there have been shifts among researchers interested in the pedagogical implementation of second language acquisition (SLA) from method-based pedagogy to postmethod pedagogy (Kumaravadivelu 2001; 2006) and from communicative language teaching (CLT) which emerged during 1970s (Skehan, 2003) to task based language teaching (TBLT) (Kumaravadivelu, 2006; Branden 2006). Some principles underlying CLT are: (1) real communicative activities through which students use a great deal of language are believed to be essential for SLA, (2) meaningful tasks, which require students to engage in meaning-related processing within those activities, support language learning, and (3) the language learning process can be promoted when the learner finds language meaningful and relevant to his genuine, realistic situations (Richards and Rodgers, 2001; Li, 1998).

However, Kumaravadivelu (2006) states three main factors that have made CLT come into questions. Firstly, teachers as practitioners in implementing CLT in their classroom tend to fail to meet the above principles of CLT especially the one that promotes authentic communication to represent the real wold (authenticity). Also, the notion of CLT is not widely accepted among scholars in SLA as CLT is considered to be lack of empirical evidence and instead CLT seems to 


\section{Muhammad Ahkam Arifin, Designing a Lesson Plan For ...}

adopt all main principles of the preceding audio-lingual method (acceptability). The last one is that the objectives advocated by CLT are found to be inappropriate to be implemented in some contexts (e.g. India, China, Japan, Pakistan, Africa, and Thailand) due to the different local linguistic, sociocultural, educational, and political situations (adaptability).

Interestingly, though, according to Richards and Rodgers (2001) TBLT advocating tasks starts emerging as vehicles to apply the same principles advocated by CLT as mentioned in the first paragraph above. Therefore, some consider TBLT is another name of CLT (Kumaravadivelu, 2006). Littlewood (2004, 2007), Nunan (2004), Richards (2005) and Harmer (2007) certainly also imply that TBLT is within a development of CTL. Furthermore, Skehan (1996; 1998) posits TBLT has the similar view of communicative language teaching as he refers "tasks" to activities that primarily focus upon meaning. Sheen (1994) argues that the advocacy of TBLT has brought uncertainty and insecurity among teachers and students, that the revolution of CLT to TBLT is unproductive, and that it is the result of the failure in seeing the validity of the large amount of research that become empirical basis for the conventional methods that TBLT sought to replace.

Similar to Sheen, Swan (2005) also certainly implies that the opinions that the traditional approaches have failed to meet the demand of teachers and students in English language teaching and learning are not well-founded, and that the advocates of those opinions are often as a result of misinterpretation of the approaches they try to challenge. He continues that another claim made in association with TBLT that it is more superior compared to other language teaching approaches based on the current SLA literature "cannot be sustained" (P. 396). Swan even warns that the theories advocating TBLT may create immerse harm to millions of learners and teachers as every year overseas students coming to English-speaking countries to study cutting-edge theory before going home to give influence in the educational policies within their countries, if the theories advocating TBLT are inappropriate to student teaching contexts. Additionally, Seedhouse (1999) reveals that he does not find any holistic analysis of evidence in the form of lesson transcripts that can demonstrate the benefits claimed by the advocates of TBLT, and he considers this omission to be puzzling. 
Volume 4, Number 01, June 2018

The above criticisms made by the authors Sheen, Swan, and Seedhouse have been responded by some advocates of TBLT such as Nunan (1994, 781-782), Long (1994), and Ellis (2009); in general the three authors mention that the criticism to question the theories of TBLT is the result of misinterpretation. Nunan, for example, claims that Sheen`s article "contains so many misleading assumptions and assertions" (p. 781), and he provides two objections. The first objection is that Sheen has failed to cite some available resources that have been written by Nunan; instead Sheen only takes the data that are only intended to criticise Nunan`s work. The second objection is that Nunan`s views are "consistently misrepresented". (p. 782). For example, Sheen posits that Nunan in mentioning the beliefs underlying TBLT has tried to show his support to Krashen`s theory of comprehensible input (CI), while Nunan himself does want to critique Krashen`s CI. It means that Sheen has mistakenly considered Krashen`s CI to have become one of the assumptions that characterizes TBLT. Krashen has hypothesized that input is sufficient for the first or second language acquisition, and humans do not acquire by practicing speaking (Gregg, 1986). However, currently it seems to be that he has changed his mind by stating that "comprehensible input is necessary but not sufficient", and that "speaking is now thought to be a result of acquisition, not a cause” (Krashen, 1983, p. 43).

Next, in giving a response to Sheen`s article, Long says that there are "numerous factual inaccuracies, confusions, non sequiturs, distortions, and gross misrepresentations of my own and others' work" (p. 782) in Sheen's article. In his article, Sheen states that it is unjustified to follow Long and Nunan`s views that methods in SLA do not exist in that teachers as practitioners do not implement the methods as expected, and that methods mostly give little or no difference in classroom implementation, which then trigger the two authors to adopt task based syllabus (TBS) as a replacement. To support his statements, Sheen mentions some studies (e.g. Spada, 1987) which are then in question by Long. Long points out that Sheen has misinterpreted the findings of Spada`s research. Spada`s study is not inconsistent with Long and Nunan`s proposal that methods have lost their integrity when teachers implement them in the classroom. This phenomenon appears to be one of the main factors that contributes to the emergence of "postmethod condition", that is, an effort to find an alternative to method, and not an alternative method (Kumaravadivelu, 1994). 


\section{Muhammad Ahkam Arifin, Designing a Lesson Plan For ...}

Lastly, Ellis (2009) attempts to sort out "the misunderstanding" (P. 221) of TBLT among researchers and teacher educators. One of the criticisms he tries to address is Widdowson`s statement that the definition of task is "loosely formulated" (2003, p. 126). Ellis admits that Widdowson is right for showing that the definition of task seems to be inconsistent as is evident in some sources which provide various definitions (e.g. Bygate, Skehan, \& Swan, 1991; Ellis, 2003; Samuda and Bygate, 2008). However, he continues that Widdowsn reaches such an understanding as Widdowson sticks to one definition that is provided by Skehan $(1996 ; 1998)$. Skehan mentions that any activities can be considered to be a task when satisfying four criteria:

- Meaning is primary.

- There is a goal which needs to be worked towards.

- The activity is outcome-evaluated.

- There is a real-world relationship (1998, P. 268).

Widdowson criticises Skehan for not being specific to what he means by "meaning" (it may either or/and both refer to semantic or pragmatic meaning), "goal", and "real-world relationship". I have mentioned some criticisms of TBLT by doing my best to arrange it according to the timeline, yet I realise that the dispute among the abovementioned linguists and others is still ongoing. And it is not this time in this paper I shall mention this; instead I will focus more on the theoretical beliefs underlying TBLT that will also be the rationale of my lesson plan within this paper.

\section{B. REVIEW OF LITERATURE}

Before going on mentioning the principle theories supporting TBLT, I think I need to, at the outset, determine what I mean by the word "task" across this paper. As admitted among its advocates (e.g. Nunan, 2004; Branden, 2006; Skehan, 1996, 2013; Littlewood, 2004; Long \& Crookes, 1992; Ellis, 2009), the definitions of task vary in TBLT, which then invites controversy among researchers (Harmer, 2009). Long`s non-technical and non-linguistic meaning, for example, refers (target) tasks to any activities that people do in everyday life, including such 
Volume 4, Number 01, June 2018

examples as buying a concert ticket, borrowing a book from the library, and writing a letter (1985).

For the definition that will be used throughout this paper, I shall refer to Branden (2006) that tasks are any activities in which students engage to reach an objective that requires them to use their language resources. This type of task is generally called "pedagogical task" (Nunan, 2004), or also "classroom task" (Calvert \& Sheen, 2014). In this respect, language is not the end of a task, yet it functions as a means to help leaners reach the objectives within those pedagogical tasks that provide attempt to reflect the real-world situations (Branden, 2006; Ellis, 2006; Willis \& Willis, 2007). Tasks having non-linguistic outcomes are in contrast to exercises (non-tasks) which have no communicative purposes (Nunan, 2004; Ellis, 2003). Estaire \& Zanon (1994) call "enabling tasks" for what Ellis names "exercises", and "communicative tasks" for what Ellis mentions as "tasks". In TBLT students may use any language resources as many as possible to achieve the task outcomes (Willis and Willis, 2001).

Inasmuch as TBLT`s focus is upon meaningful communication, yet without neglecting the importance of the grammatical knowledge, I think it may suite my student needs who come to my class to improve their communicative skill, but still want to learn grammar as most of English tests in my country, Indonesia, still requires accuracy and even explicit grammatical knowledge (e.g. the TOEFL ITP). Considering that Nunan`s model seems to be more specific than other models of TBLT (e.g. Willis, 1996; Ellis, 2003), I will use Nunan`s six-step model for my lesson plan.

\section{Schema Building}

The first step of Nunan`s model of TBLT is to activate student schematic knowledge; it is interchangeably used with background knowledge (Carrell, 1983; Hedge, 2001). In the field of cognitive psychology, it is plausible that the activation of schema(ta) that attempts to relate student existing knowledge structure with the new experience can provoke student interest into the topic of language learning (Carrell, \& Wise, 1998). Schema building may then assist students perform tasks more easily (Nunan, 2004).

To lead my students into contexts and to introduce the topic along with the relevant vocabularies and expressions in relation to the tasks that students will have to perform at a later stage (Nunan, 2004), I provide some pictures related to the topic of the tasks, that is, the pictures 


\section{Muhammad Ahkam Arifin, Designing a Lesson Plan For ...}

of the top universities around the world (see Appendix 2). One of the objectives of my lesson is to enable my students to tell about the popular universities and the majors. While showing the pictures to them, I also ask some relevant questions that will encourage them to start using vocabularies and expressions that are relevant to the learning topic. As scaffolding is initiated in this first step (Nunan, 2004), I have put some possible questions to ask by the teacher and some example of the answers that may scaffold the students in creating their own unique answers (see Appendix 2). I expect that this topic would be easier for my students as the topic of top universities is familiar to all of my students (Nunan, 2004).

Still in relation to this aspect, I suppose that this familiar topic can engage my students into participating and being proactive and that may ease them into active learning. In the field of SLA, it is plausible that successful learning requires student active engagement (Saville-Troike, 2006; 2012). Not only is it specific to language learning, but it also applies to other types of learning (Littlewood, 2004). Furthermore, as my students have the motivation to pursue their master`s or doctoral degree, this topic, I expect, could motivate them to be more active to complete the tasks. I do concern in actively encouraging my students to have good motivation in language learning in that I believe that motivation as a cognitive force is one of the keys to ultimate level of proficiency in SLA (Saville-Troike, 2006; 2012; Rost \& Wilson, 2013).

\section{Controlled Practice}

In this step, with controlled practice students are scaffolded in using language vocabulary, structures, and functions that they can use later (Nunan, 2004). One way to do this is to provide a short conversation related to the topic. Students will listen, read, and at the end practice (speak) the conversation with a partner. One major reason to do this, according to Nunan, is to allow students to see, hear, and practice the target language that will be useful for completing the tasks at a later stage. This will also help learners to start actively using the language in that TBLT puts the importance of the notion that students can learn best through doing (active learning) (Nunan, 2004). In attempting to meet the above criteria, I have provided a conversation between a man and woman talking about the woman`s university major (see Appendix 3). My students will first 
Volume 4, Number 01, June 2018

look at the conversation for a while, and then listen to the audio of that conversation. After that, my students then practice it in pairs.

Seemingly, one of the reasons for this step is because the advocates of TBLT believe that students not only acquire language through input but also output (e.g Ellis, 2003; Nunan, 2004; Swain 1985 in Fotos and Ellis). Therefore, tasks can be both input based (e.g. listening and reading) and output based (e.g. speaking and writing), and that tasks provide students opportunities to practice the four language skills. Typically in TBLT tasks are integrative, that is, two or more skills are involved. A study by Sung and Soh (2008) demonstrates that students provided with output opportunities can have significantly greater noticing that leads acquisition than students who receive no output opportunities. This principle of TBLT also distinguishes it from Krashen`s CI theory that was once believed to be sufficient for language acquisition.

Furthermore, this step should be clearly distinguished from controlled practice in the presentation-practice-produce model (PPP) in that in PPP forms are introduced to students at the beginning before going into controlled practice. Although it seems to mirror the PPP model as Nunan puts forms before the task (Littlewood, 2004); the selection of activities for controlled practice in PPP and TBLT is different. Whilst in PPP students are encouraged to practice the forms (e.g. through drills) (Carless, 2009), TBLT provides the language within contextualized model. PPP model focuses more on student accuracy of language, while TBLT prefers student fluency over accuracy.

\section{Authentic Listening Practice}

Before proceeding to the theories underlying this step, I would first define what I mean by authentic material across my paper. Authenticity may be divided into two different types that are used in TBLT: situational authenticity and interactional authenticity (Ellis, 2003; 2009). The former refers to any tasks that provide students for natural language use, that is, corresponding real-world activities (life likeness), while the latter, also called interactiveness (Bachman \& Palmer, 1996), concerns with student engagement with the tasks. It means that activities within TBLT can be considered to be tasks when they can engage students (Guariento and Morley, 2001, p. 350).

Nunan (2004) refers authenticity to any materials (e.g. written and spoken materials) that are originally designed not for language teaching purposes. However, Nunan admits that tasks in TBLT should not be limited to this definition as what matters is that how students can be 


\section{Muhammad Ahkam Arifin, Designing a Lesson Plan For ...}

engaged with those tasks that may lead to the creation of optimal learning opportunities. Breen (1985) appears to have proposed the similar definition as he admits that the recent argument towards authenticity is to expose learners to immediate and direct contact with input that are genuinely in nature, and he continues that authentic materials should engage students in giving their effort for active communication.

Seemingly, though, to me they all implicitly state the similar notion that tasks in TBLT which are authentic in nature are not limited to the materials that have originally been produced for communication purposes not for language learning as the important thing for tasks is to have students get involved in completing the tasks (task-involvement). In general, authentic materials are always associated with native speakers of English (e.g. Willis, 1996; Richards and Rodgers, 2001; Nunan, 2004) in Kachru`s inner circle (Kachru, 1992). However, in designing materials for this step I will not limit myself to this definition. I don't want my students to have less confidence in spoken English in that they will never have the opportunity to be native-like fluency. I share the same view of the notion of Global Englishes (GE) that attempts to raise awareness of the different types of English around the world (e.g. Galloway and Rose, 2014; Galloway, 2013; Jenkins, 2006).

To meet the criteria of authentic listening in this step, I provide a YouTube video showing seven students from different countries including Kachru`s inner circle stating the reason for choosing their college major (see Appendix 4). Within this activity, my students will have to watch the video and answer the questions by filling in the blank that I have provided (see Appendix 4). Of the seven questions, I have provided the answer the first number as an example; I suppose they can be scaffolded with it. Also, to complete the tasks, I will divide into small groups (in three) so that they can share their answers and that would let them have more interaction among them and get scaffolded.

The above activity is to activate my student top-down processing, which is knowledge based. This type of processing requires students to focus on the ideas rather than on the language structures, words or sounds as in bottom-up processing (Rost \& Wilson, 2013). Focusing upon building understanding of complex ideas has been considered to be a key to student listening 
Volume 4, Number 01, June 2018

development (Ibid). Another central principle underpinning the top-down approach is schemata theory (Nunan, 1997). In the first step there has been schema building, so my students have already been scaffolded to activate their schematic knowledge. If my students cannot complete the tables after sharing answers with their friends within their small groups, I will play the video again as suggested by Nunan (ibid) with the hope that it can be challenging to them and provide more exposure to input.

\section{Focus on Linguistic Elements}

This step focusing more upon form (e.g. lexical, grammatical, and phonological elements) is expected to raise student awareness to see the interrelation between linguistic knowledge and communicative meaning rather seeing them as separated and isolated elements as is often the case in more conventional approaches (Nunan, 2004). Unlike the TBLT model proposed Willis (1996) who puts language focus in the end of the lesson or after the task stage, Nunan puts language focus before students complete the task as Nunan points out that students should not be expected to produce language that has not been previously implicitly or explicitly introduced.

As my objective is to improve my student use of subordinating conjunction (but, or, and, so) and coordinating conjunction (because), I have provided my students with what a grammar task (see Appendix 5) that would, hopefully, allow them to analyse and practice specific linguistic features that may be useful for them to use for the task completion at a later stage. To solve this grammar task, my students will have to have active interaction with their partner. Student A gets a card that contains cut sentences (in half), and the other half are in the student B card. For example, student A reads the first cut (half) sentence "You may think that you have found your perfect college, ...” and students B will say “... but you realize that the climate is too cold or too hot for you". Again, this interactive activity is to fulfil my expectation to have my students become aware that grammatical knowledge has to be connected with language use and meaning (Fotos and Ellis, 1991; Goh \& Burns, 2012).

\section{Provide Freer Practice}

The previous steps have involved my students in "reproductive" language work (Nunan, 2004). Nunan also proposes the contribution of "receptive-to-productive" principle. This step will have the students engage in freer practice by using any language resources they have to 


\section{Muhammad Ahkam Arifin, Designing a Lesson Plan For ...}

complete the task. It is also associated with Swain`s comprehensible output principle (1985) in that learners are pushed to produce any language for the task completion (Nunan, 2004).

In this step, I would divide my students in group of three to have role play (see Appendix 5). One of them would be the interviewer acting as a university staff who is recruiting students to his university. The two others would be the students who are enrolling to the university. In the end, one of the students will be selected as a nominee. Hopefully, this activity can engage and motivate my students and that leads to the development of their fluency in using the target language in that they have the opportunity to express themselves freely with their own ideas and experience (Hedge, 2000).

\section{Introduce the Pedagogical Task}

In this step, my purpose is to make my students realise that in the end they can do the (pedagogical) task by themselves without any support (scaffolding). I remove the scaffolding in this step in order that my students can be independent in their learning and that leads to learner autonomy (Nunan, 2004; Goh \& Burns, 2012). Hopefully, my students can be highly motivating as they have seen themselves working through the sequence (ibid). With the increase of my student motivation, they will be able to deal with their anxiety and risk-taking (Gardner, Tremblay \& Masgoret, 1997) and increase their self-confidence (Aragão, 2011).

My students will have to have a-two-minute speech about the major that they are going to take in the future along with the reasons and I will allow them to plan the task around three minutes. With the pressure time, I expect it can be more challenging to my students (Ellis, 2003) and hopefully can also be motivating.

\section{EVALUATION}

The general consensus of using tasks is to provide communicative language use that tend to focus on the negotiation of meaning rather than the grammatical forms as advocated by traditional language instruction that applies a syntactic syllabus (Ellis, 2009). That is, the primary focus is not on language learning, yet on language use (Tomlinson, 2008; Harmer, 2007). It does not mean that grammar has no place in TBLT (Nunan, 2004) as it can also be explicitly taught after the focus on meaning has been completed (Willis and Willis, 2007; Samuda, 2001). 52 
Volume 4, Number 01, June 2018

Nunan in his model of TBLT, in contrast, demonstrates that the focus on form may precede the focus on meaning in that grammatical knowledge may help students in expressing meaning. I am aware that there has been an effort to distinguish the use of the terms "form", "forms", and "language" as proposed by Willis and Willis when comparing their terms to Long`s uses of "form", "forms", and "language", yet I tend not to use these differences in this paper. The use of meaning focus and form focus, or focus on forms (e.g. grammar exercise), I think, can be clearly understood, and these two terms should be enough to explain TBLT.

In my lesson plan, I tend to use pair or group work in that interaction is central within the theories of TBLT. Through interaction students have the opportunity to negotiate meaning and that makes them acquire (Skehan, 2003). If seen from sociocultural theory (SCT), interaction not only facilitates learners to acquire but also it could be a causative force in acquisition (SavilleTroika, 2006; 2012). Negotiation of meaning in this paper is concerned with the way students deal with difficulties in communication to complete tasks (Skehan, 2003). A study done by Pica and Doughty (1985) demonstrates that group and pair based interactions provide more conversational modification in that interaction requires students to exchange information. However, Ellis (2003) asserts that in TBLT tasks can be performed by students not only through pair or group work but also individually.

Related to the theory of interaction, another salient theory in TBLT is "scaffolding", which is mostly developed within sociocultural approach in SLA. Scaffolding is any verbal guidance provided by an expert to assist leaners to perform tasks; an expert in this case is mostly referred to native speakers and teachers, yet it may also refer to students in peer or group collaboration while performing too difficult tasks to complete as individually (Saville-Troika, 2006; 2012).

A study carried out by Li (1998) shows that through peer collaboration students have more interest in providing scaffolding particularly for clarifying meaning and noticing forms; noticing in TBLT is also another central feature as it is regarded as a requisite in SLA (Schmidt, 1994). Inasmuch as TBLT encourages more on peer and group collaboration, TBLT is then can be regarded as student-centred (Willis \& Willis, 2007; Branden, 2006), which is to make students more participative in classroom (active learning), although Ellis also states that TBLT can be both learner-centred and teacher-centred. 


\section{Muhammad Ahkam Arifin, Designing a Lesson Plan For ...}

However, I have to acknowledge that peer or group work may not always provide scaffolding as expected as shown in Kay-Aydar`s study (2003) that students-led discussion has failed to provide appropriate scaffolding as certain students dominate more while negotiating meaning. Kay-Aydar reveals that teachers can give more scaffolding to students, so in my lesson plan I will always do monitoring to scaffold my students except in the last step, that is, pedagogical task in which students have to carry out their tasks individually.

\section{CONCLUSION}

With the post-method condition, it is now widely believed that there is no single method or set of procedures that suite all student needs and fit all different contexts of language learning. Current research clearly shows the fundamental rise of tasks in TBLT among researchers and teacher educators in the field of SLA. Notwithstanding its criticism, TBLT seems to have more advantages than disadvantages. TBLT`s principle is to balance between language use, language meaning, and language forms; all skills and elements are integrated and not separated as is typical in traditional approaches. However, as there have been so many different opinions (e.g. how task is defined) among its advocates, understanding TBLT should not be limited to one or two authors. We have to be open to receive all coming ideas in that all of those ideas are purely intended to help students learn English effectively and efficiently.

\section{REFERENCES}

Aragão, R. (2011). Beliefs and emotions in foreign language learning.System, 39(3), 302-313.

Bachman, L. F., \& Palmer, A. S. (1996). Language testing in practice: Designing and developing useful language tests (Vol. 1). Oxford University Press.

Breen, M.P. (1985). Authenticity in the language classroom. Applied Linguistics, 6(1), 60-70.

Carless, D. (2009). Revisiting the TBLT versus PPP debate: Voices from Hong Kong. Asian Journal of English Language Teaching, 19(1), 49-66.

Carrell, P. L. (1983). Some issues in studying the role of schemata, or background knowledge, in second language comprehension. Reading in a foreign language, 1(2), 81-92. 
Volume 4, Number 01, June 2018

Carrell, P. L., \& Wise, T. E. (1998). The relationship between prior knowledge and topic interest in second language reading. Studies in second language acquisition, 20(03), 285-309.

Nunan, D. (2004). Task-based language teaching. Cambridge University.

Ellis, r. (2003). Task-based language learning and teaching. Oxford: Oxford University Press.

Ellis, R. (2009). Task-based language teaching: sorting out the misunderstandings. International Journal of Applied Linguistics, 19(3), 221-246.

Estaire, S. and J. Zanon. (1994) Planning Classwork: A Task-based Approach. Oxford: Macmillan Heinemann. Littlewood,

Farrell, T. S. (2002). Lesson planning. Methodology in language teaching: An anthology of current practice, 30-39.

Fotos, S., \& Ellis, R. (1991). Communicating about grammar: A task-based approach. TESOL quarterly, 605-628.

Galloway, N. (2013). Global Englishes and English Language Teaching (ELT)-Bridging the gap between theory and practice in a Japanese context.System, 41(3), 786-803.

Galloway, N., \& Rose, H. (2014). Using listening journals to raise awareness of Global Englishes in ELT. ELT Journal, ccu021.

Gardner, R. C., Tremblay, P. F., \& Masgoret, A.-M.. (1997). Towards a Full Model of Second Language Learning: An Empirical Investigation. The Modern Language Journal, 81(3), 344-362.

Goh, G., Goh, C., \& Burns, A. (2012). Teaching Speaking: a holistic approach. Cambridge: Cambridge University Press.

Gregg, K. R.. (1986). [Review of The Input Hypothesis: Issues and Implications]. TESOL Quarterly, 20(1), 116-122.

Guariento, W. and Morley, J. (2001). Text and Task Authenticity in the EFL Classroom. ELT Journal, 55, (4), 347-353.

Harmer, J. (2007). How to teach English. London: Longman.

Harmer, J. (2009). Doing Task-Based TeachingTasks in Second Language Learning. ELT journal, 63(2), 173-176.

Hedge, T. (2001). Teaching and learning in the language classroom (Vol. 106). Oxford,, UK: Oxford University Press. 


\section{Muhammad Ahkam Arifin, Designing a Lesson Plan For ...}

Jenkins, J. (2006). Current perspectives on teaching world Englishes and English as a lingua franca. Tesol Quarterly, 40(1), 157-181.

Kachru, B. B. (1992). World Englishes: Approaches, issues and resources.Language teaching, 25(01), 1-14.

Kayi-Aydar, H. (2013). Scaffolding language learning in an academic ESL classroom. ELT journal, 67(3), 324-335.

Krashen, S. D. (1983). The din in the head, input, and the language acquisition device. Foreign Language Annals, 16(1), 41-4.

Kumaravadivelu, B. (1994). The postmethod condition: (E)merging strategies for second/foreign language teaching. TESOL Quarterly, 28, 27-48.

Kumaravadivelu, B.. (2001). Toward a Postmethod Pedagogy. TESOL Quarterly, 35(4), 537-560.

Kumaravadivelu, B.. (2006). TESOL Methods: Changing Tracks, Challenging Trends. TESOL Quarterly,40(1), 59-81.

Li, D.. (1998). "It's Always More Difficult Than You Plan and Imagine": Teachers' Perceived Difficulties in Introducing the Communicative Approach in South Korea. TESOL Quarterly, 32(4), 677-703.

Littlewood, W. (2004). The task-based approach: Some questions and suggestions. ELT journal, 58(4), 319-326.

Littlewood, W. (2007). Communicative and task-based language teaching in East Asian classrooms. Language teaching, 40(03), 243-249.

Long, M. (1985) A role for instruction in second language acquisition: task-based language teaching. In K. Hyltenstam and M. Pienemann (eds.), Modelling and assessing second language acquisition. Clevedon: Multilingual Matters.

Long, M. H.. (1994). Two Commentaries on Ron Sheen's "A Critical Analysis of the Advocacy of the Task-Based Syllabus": On the Advocacy of the Task-Based Syllabus. TESOL Quarterly, 28(4), 782-790.

Long, M., \& Crookes, G. (1992). Three approaches to task-based syllabus design. TESOL Quarterly, 26, 27-56. 
Volume 4, Number 01, June 2018

Marshan, S. (2015). Developing English Morphology Materials For Undergraduate Students At Alauddin State Islamic University Of Makassar. ETERNAL (English, Teaching, Learning, and Research Journal), 1(1), 1-14.

Nunan, D. (1997). Approaches to teaching listening in the language classroom. In Plenary (p. 1).

Nunan, D.. (1994). Two Commentaries on Ron Sheen's "A Critical Analysis of the Advocacy of the Task-Based Syllabus": A Reader Reacts. TESOL Quarterly, 28(4), 781-782.

Nurpahmi, S. (2013). An Introduction to English for Specific Purposes. Makassar: Alauddin University Press.

Nurpahmi, S. (2014). English for Specific Purposes: An Integrated Approach. Makassar: Alauddin University Press.

Nurpahmi, S. (2017). ESP Course Design: An Integrated Approach. Lentera Pendidikan: Jurnal Ilmu Tarbiyah Dan Keguruan, 19(2), 172-181. DOI:http://doi.org/1024252/lp.2016v19n2a4

Pica, T. \& Doughty, C. (1985). Input and interaction in the communicative language classroom: A comparison of teacher-fronted and group activities. In S. Gass \& C. Madden (Eds.), Input and second language acquisition, Rowley, Mass: Newbury House.

Richards, J. C. (2005). Communicative language teaching today. Singapore: RELC.

Richards, J. C., \& Rodgers, T. S. (2001). Approaches and methods in language teaching. Cambridge University Press.

Rost, M., \& Wilson, J. J. (2013). Active Listening. Routledge.

Samuda, V. (2001) 'Guiding relationships between form and meaning during task performance: the role of the teacher' in M. Bygate, P. Skehan, and M. Swain (eds.). Researching Pedagogic Tasks. London: Longman.

Samuda, V., \& Bygate, M. (2008). Tasks in second language learning. Basingstoke: Palgrave Macmillan.

Schmidt, R. (1994) Deconstructing consciousness in search of useful definitions for applied linguistics. AIL A Review 11: 11-26.

Seedhouse, P. (1999) Task-based interaction. ELT Journal 53: 149-56.

Sheen, R.. (1994). A Critical Analysis of the Advocacy of the Task-Based Syllabus. TESOL Quarterly,28(1), 127-151. 


\section{Muhammad Ahkam Arifin, Designing a Lesson Plan For ...}

Skehan, P. (1996). Second language acquisition research and task-based instruction. In J. Willis and D. Willis (eds.). Challenge and Change in Language Teaching. Oxford: Heinemann. 17-30.

Skehan, P. (1998) Task-based instruction. Annual Review of Applied Linguistics 18: 268-86

Skehan, P. (2003). Task-based instruction. Language teacbing, 36(01), 1-14.

Song, M. J., \& Suh, B. R. (2008). The effects of output task types on noticing and learning of the English past counterfactual conditional. System,36(2), 295-312.

Song, M. J., \& Suh, B. R. (2008). The effects of output task types on noticing and learning of the English past counterfactual conditional. System,36(2), 295-312.

Spada, N. (1987). Relationships between instructional differences and learning outcomes: A process-product study of communicative language teaching. Applied Linguistics, 18, 137-161.

Swain,M. (1985).Communicative competence: Some roles of comprehensible input and comprehensibl output in its development. In S. Gass \& C. Madden (Eds.), Input in second language acquisition (pp.235-253). Rowley, MA: Newbury House.

Swan, M. (2005). Legislation by hypothesis: The case of task-based instruction. Applied Linguistics, 26(3), 376-401.

Tomlinson, B. (2008). Doing Task-Based Teaching Task-Based Language Education. ELT journal, 62(1), 92-95.

Van den Branden, K. (Ed.). (2006). Task-based language education: From theory to practice. Cambridge University Press.

Widdowson, H. (2003). Defining issues in English language teaching. Oxford University Press.

Willis, J. (1996) A flexible framework for task-based learning. In J. Willis and D. Willis (eds.), 235-256 Challenge and Change in Language Teaching. Oxford: Heinemann. 52-62.

\section{APPENDIX}

\section{Appendix 1. Lesson Plan: Choosing a University Major}




\section{Group:}

Intermediate adult students; the students are well-educated. They all have done their bachelor`s degree; one of them has a master`s degree. They take this class (course / programme) for international communication. Their overall goal is to be able to communicate in English. They have appropriate motivation to study English, yet still find themselves anxious to speak; they are afraid of making mistakes / errors (less accuracy). One of the students have better communication skill yet has problems with linguistic knowledge (grammar). Two of them have good knowledge of English structures yet less fluency. The others tend to have balanced abilities (accuracy and fluency). I have good relation with them; we sometimes go out eating dinner after the class before going home (the class starts at $7 \mathrm{pm}$; they work at day time).

\section{Recent topic work:}

Last meeting we talked about environmental issues (also quite related to health issues) in Indonesia especially in Makassar (the city where we live in) along with the student propose of solutions, and how far the government along with the society in Makassar had tried to handle the issues.

\section{$\operatorname{Aim}(\mathrm{s}):$}

- To develop student listening ability about choosing a college or university major. Albeit they already work, they still have the motivation to do their master`s or doctoral degree abroad (they tend to mention the UK and the USA).

- To develop student communication ability about reason for choosing a college or university major.

\section{Duration: 90 mins}

Date:

No. of students: 6 (six)

\section{Recent language work:}

Ss have so far learnt that each sentence in English has a subject and verb. They also have learnt about past and present participle and appositives.

\section{Materials:}

You tube videos, pictures of top universities around the world presented, two loud speakers, printed material

\section{Reflection (to be completed after delivery)}

By the end of this lesson, SS should be able to:

- Tell about the popular universities and the majors.

- Describe their reasons of choosing a major (it may be specified in terms of their bachelor`s major or their proposed master`s or doctoral degree preference).

- Apply the use of the connecting words "but" "or" "so" and "because" in explaining their reasons for choosing a college or university major.

The action verbs are taken from Farrel (2002); the objectives try to meet Bloom's taxonomy of thinking process (Shrum \& Glisan, 1994).

Anticipated problems:

The internet connection sometimes drops out, so T has downloaded the videos in advance. 
Muhammad Ahkam Arifin, Designing a Lesson Plan For ...

\begin{tabular}{|c|c|c|c|c|c|c|}
\hline \multicolumn{4}{|c|}{$\begin{array}{l}\text { Anticipating the sound of the video is not very clear to students, } T \text { has prepared tow loud speakers and has } \\
\text { already put them in the class. }\end{array}$} & \multirow[b]{2}{*}{ Interaction } & \multirow{2}{*}{ Skills } & \multirow{2}{*}{ Materials } \\
\hline Time & Stage & Teacher Activity & Student Activity & & & \\
\hline 7 & $\begin{array}{l}\text { Schema } \\
\text { Building }\end{array}$ & $\begin{array}{l}\text { T. asks ss to see the pictures of top universities } \\
\text { around the world and ask them some questions } \\
\text { that may activate student schematic knowledge } \\
\text { (see Appendix 2) }\end{array}$ & $\begin{array}{l}\text { Ss look at the photos in their printed } \\
\text { material and answer T`s questions (see } \\
\text { Appendix } 2 \text { for the list of questions and } \\
\text { examples of answers). }\end{array}$ & $\mathrm{T}-\mathrm{SS}$ & $\begin{array}{l}\text { Speaking } \\
\text { Listening }\end{array}$ & $\begin{array}{l}\text { Printed Material } \\
\text { (App. 2) }\end{array}$ \\
\hline 20 & $\begin{array}{l}\text { Controlle } \\
\text { d Practice }\end{array}$ & $\begin{array}{l}\text { T asks ss to be in pairs to see, listen, and } \\
\text { practice (speak) the conversation (see } \\
\text { Appendix 3). }\end{array}$ & $\begin{array}{l}\text { With a partner, ss see, listen, and practice } \\
\text { (speak) the conversation (see Appendix 3). }\end{array}$ & SS-SS & $\begin{array}{l}\text { Listening } \\
\text { Speaking }\end{array}$ & $\begin{array}{l}\text { Printed Material } \\
\text { (App. 2) }\end{array}$ \\
\hline 20 & $\begin{array}{l}\text { Authentic } \\
\text { listening }\end{array}$ & $\begin{array}{l}\text { T. tells SS they are going to watch a short } \\
\text { Youtube video with seven students telling their } \\
\text { reason(s) for choosing their major at university. } \\
\text { T put the students into group of three } \\
\text { https://www.youtube.com/watch?v }=\mathrm{vcOKHr} \\
\text { qfMws }\end{array}$ & $\begin{array}{l}\text { Ss watch the short Youtube video with } \\
\text { seven students telling their reason(s) for } \\
\text { choosing their major at university. } \\
\text { Ss in group of three will have to will have } \\
\text { to answer the questions by filling in the } \\
\text { blank that I have provided (see Appendix } \\
\text { 4). } \\
\text { Ss in the end share their answers to the } \\
\text { other group members. }\end{array}$ & $\begin{array}{l}\text { SS-SS } \\
\text { T-SS }\end{array}$ & Listening & $\begin{array}{l}\text { Printed Material } \\
\text { (App. 2), A loud } \\
\text { speaker, } \\
\text { Projector (PPT) }\end{array}$ \\
\hline 13 & $\begin{array}{l}\text { Linguistic } \\
\text { elements }\end{array}$ & $\begin{array}{l}\text { T distributes two interactive cards for students } \\
\text { in pairs. (see Appendix 5). }\end{array}$ & $\begin{array}{l}\text { Student A gets a card that contain cut } \\
\text { sentences in half, and the other half are in } \\
\text { the student B card. For example, student A } \\
\text { reads the first cut (half) sentence "You may } \\
\text { think that you have found your perfect } \\
\text { college,..." and students B will say "... but }\end{array}$ & SS-SS & Speaking & Cards (App 5) \\
\hline
\end{tabular}




\begin{tabular}{|c|c|c|c|c|c|c|}
\hline & & & $\begin{array}{l}\text { you realize that the climate is too cold or } \\
\text { too hot for you". }\end{array}$ & & & \\
\hline 10 & $\begin{array}{l}\text { Freer } \\
\text { practice }\end{array}$ & $\begin{array}{l}\text { Role play } \\
\mathrm{T} \text { asks the students to be in two groups (there } \\
\text { are seven ss, so one group will be in three and } \\
\text { the other in four). Each group has one } \\
\text { interviewer whose job is to select one student } \\
\text { with the best reason for his university program. } \\
\mathrm{T} \text { tells the student acting as the interviewer to } \\
\text { ask any questions that can make him convinced } \\
\text { in choosing the right candidate to his program. } \\
\text { After each group has finished choosing their } \\
\text { candidate, each group reports to teacher about } \\
\text { their chosen student and the reason to choose } \\
\text { him. }\end{array}$ & $\begin{array}{l}\text { Ss are in two groups (each consisting } \\
\text { three). Each group selects one interviewer } \\
\text { whose job is to select one student of the } \\
\text { two with the best reason for his university } \\
\text { program. } \\
\text { All ss select the same university program. } \\
\text { After each group has finished choosing } \\
\text { their candidate, each group reports to } \\
\text { teacher about their chosen student and the } \\
\text { reason to choose him. }\end{array}$ & $\begin{array}{l}\text { SS-SS } \\
\text { T-SS }\end{array}$ & Speaking & $\begin{array}{l}\text { Printed material } \\
\text { (Appendix 6) }\end{array}$ \\
\hline 20 & $\begin{array}{l}\text { Pedagogi } \\
\text { cal Task }\end{array}$ & $\begin{array}{l}\text { T asks ss to make a two-minute prepared } \\
\text { speech about the university to which they } \\
\text { would like to apply in the future along with the } \\
\text { reason and how they will be able to pass the } \\
\text { selection process. } \\
\text { T gives ss three to five minutes to to prepare } \\
\text { their speech. }\end{array}$ & $\begin{array}{l}\text { Ss have three to five minutes to make a } \\
\text { two-minute prepared speech about the } \\
\text { university to which they would like to } \\
\text { apply in the future along with the reason } \\
\text { and how they will be able to pass the } \\
\text { selection process. }\end{array}$ & SS-SS & Speaking & Student notes \\
\hline
\end{tabular}

Farrell, T. S. (2002). Lesson planning. Methodology in language teaching: An anthology of current practice, 30-39. 
Muhammad Ahkam Arifin, Designing a Lesson Plan For ...

Appendix 2. These pictures are mostly taken from google.com

\section{Schema Building}
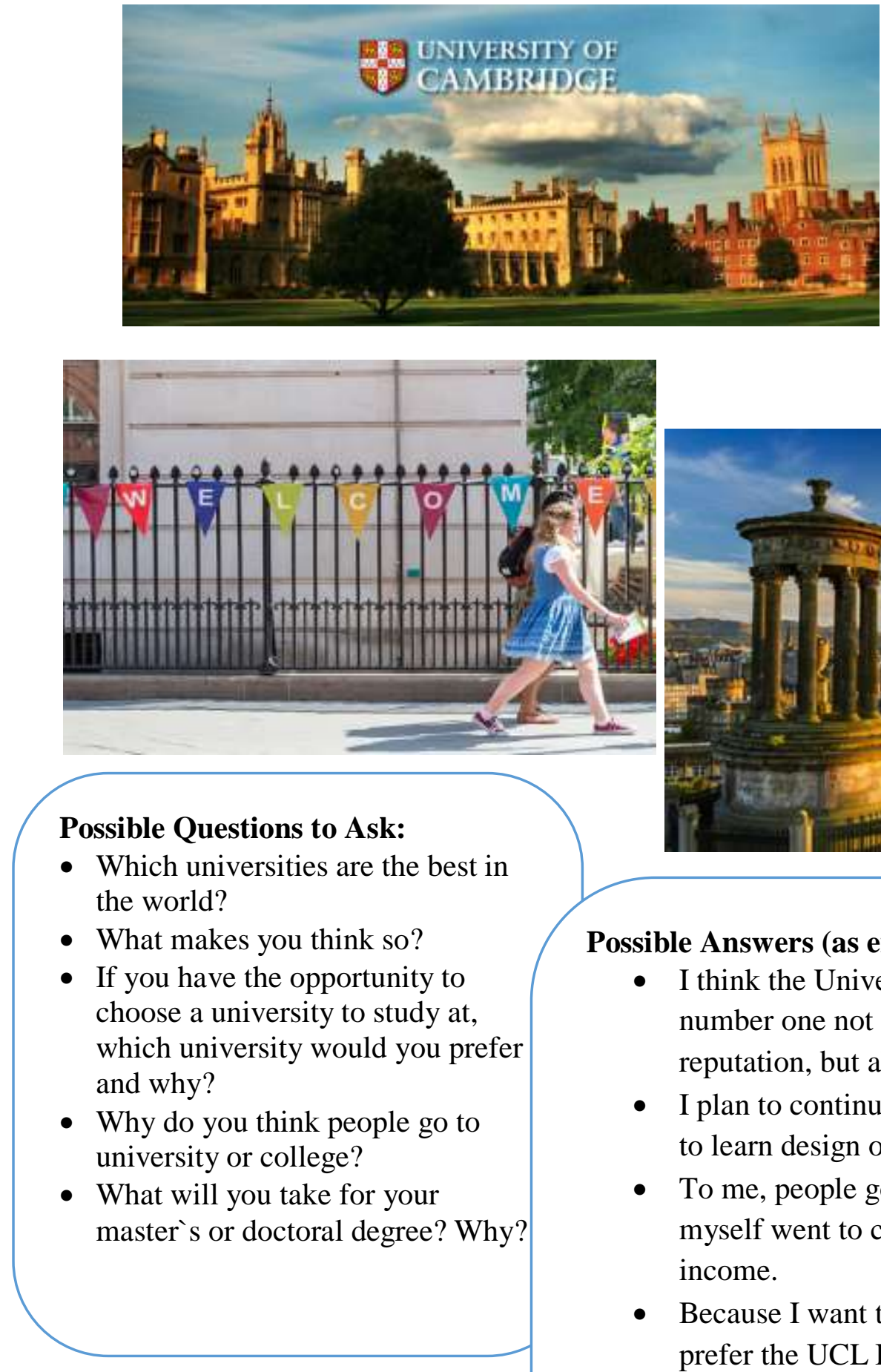

Possible Answers (as examples):

- I think the University of Cambridge now is top number one not only for its excellent world-wide reputation, but also for its top academic standards.

- I plan to continue my study in fashion because I want to learn design or merchandising.

- To me, people go to college to have a good salary as I myself went to college, so I can work with a good income.

- Because I want to be a professional teacher, I would prefer the UCL Institute of Education.
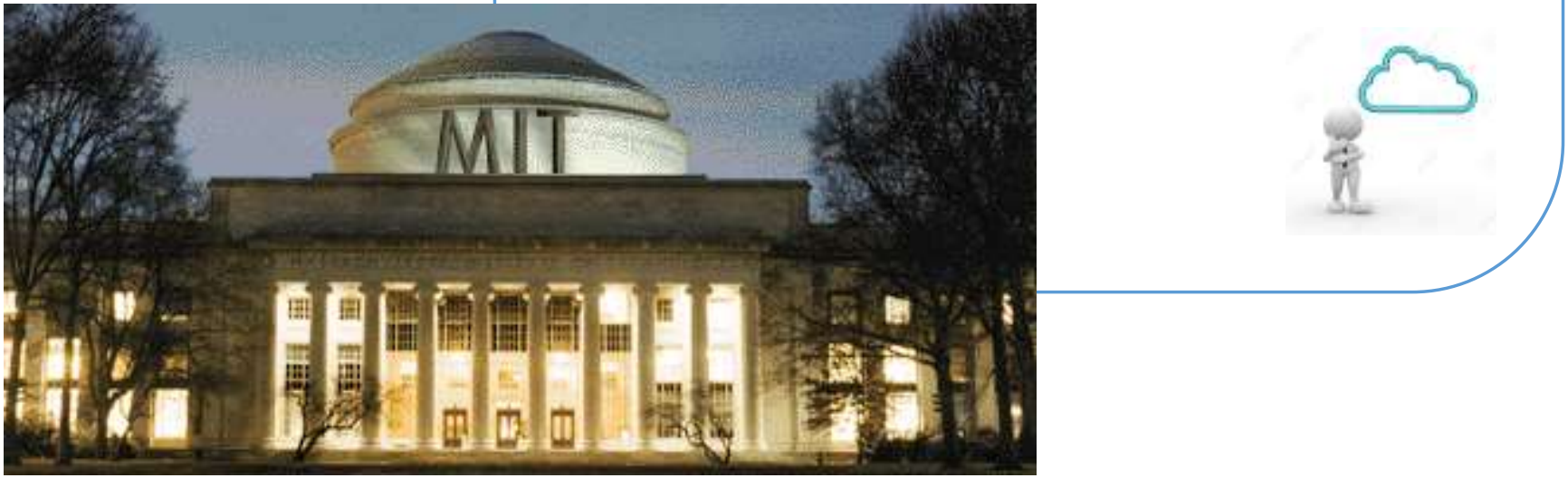
Volume 4, Number 01, June 2018

\section{Appendix 3}

\section{Controlled Practice}

Why course did you take?

\section{A Look at the extract below and listen.}

Michael: Hi Anne. Long time no see huh. ........re you, so far?

Anne: Well, I am fine, thanks. How about you?

Michael: I am fine too. I heard from Anton that you got into the University of Oxford. Is that true?

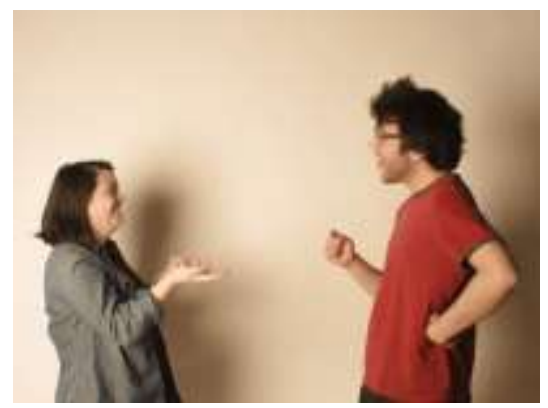

Anne: Well I never believed that I could have such an amazing opportunity. But it was not easy to meet all the requirements.

Michael: Well, you made it. I think you deserved it. You are the smartest student in our high school. Everyone knows that.

Anne: Thanks. I hope I can do well on my studies.

Michael: I believe you can make it. So, what course did you take?

Anne: I'd love to be a doctor, so I can help sick people. There are so many people who need help for their health.

Michael: What a nice goal you have, Anne! I’m proud of you.

Anne: Thank you Michael.

B Practice the conversation with a partner. 


\section{Appendix 4. Authentic Listening}

You will watch a YouTube video showing some students stating their reasons for choosing their major. Fill in the blanks. An example has been provided for you.

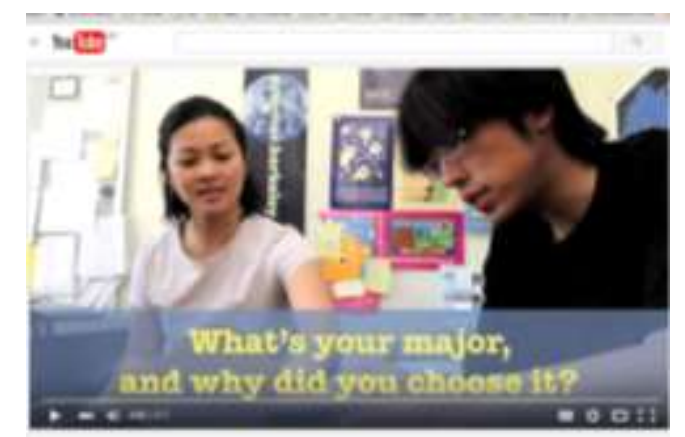

(Taken from https://www.youtube.com/watch?v=vcOKHrqfMws)

\begin{tabular}{|c|c|c|}
\hline No & The Student Major & The Reason(s) for Choosing the Major \\
\hline 1 & Civil Engineering & Hopefully, in the future I can take over my father`s company. \\
\hline 2 & & \\
\hline 3 & & \\
\hline 4 & & \\
\hline 5 & & \\
\hline 6 & & \\
\hline
\end{tabular}




\section{Appendix 5. Language Focus (Grammar)}

In pairs, each student will get a different card. Card 1 is for student A; Card 2 is for student B. Match your sentences with your partner by having conversation (interaction).

1. You may think that you have found your perfect college, ....

2. University rating system provides you information about how universities are assessed, ....

3. The quality of that university is very high as far as I am aware, ....

4. A double degree course may be great for you,

5. I am planning to get my degree in that university

6. Are you going to continue your study next year,

7. I don't like the subject I am studying, ....
A. so I would apply to it.
B. or you just want to apply for a job?
C. because you have the opportunity to get the best out of both subjects.
D. and why one university ranks above another.
E. because it has the best social and sporting facilities
F. but I have to take it.
G. but you realize that the climate is too cold or too hot for you.

Match your answers by filling the following table

\begin{tabular}{|l|l|l|}
\hline No & Student A Column & Student B Column \\
\hline 1 & & \\
\hline 2 & & \\
\hline 3 & & \\
\hline 4 & & \\
\hline 5 & & \\
\hline 6 & & \\
\hline 7 & & \\
\hline
\end{tabular}


Appendix 6. (The following pictures are taken form Google Images)

Freer Practice (Role Play)

Within group in three, one of you would be the interviewer acting as a university staff who are recruiting students to their university and the others would be the students who are enrolling to the university. In the end, one of the students will be selected as a nominee. Prepare your best answers!
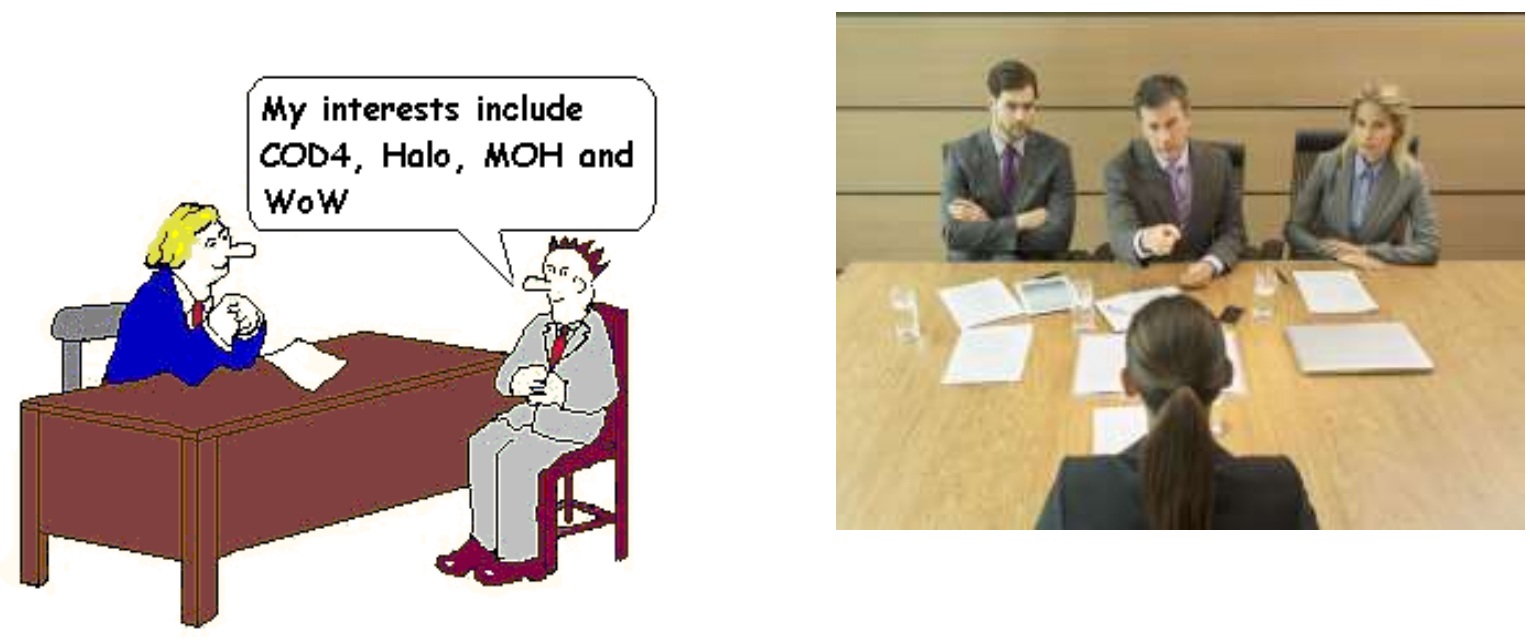

\section{Questions About Your Course/Degree}

- How did you come to choose your degree/discipline?

- Why did you come to this college/university?

- What do you like most/least about your subject?

- What class of degree do you anticipate gaining? why?

- How will your studies relate to your work?

- How have your studies been funded?

- Tell me about any project work you've undertaken?

- What is your strongest/weakest subject?Why? 